Note

\title{
Occurrence of the rare marine littoral millipede, Thalassisobates littoralis (Diplopoda: Nematosomatidae), in Canada
}

\author{
Donald F. McAlpine
}

New Brunswick Museum, 277 Douglas Avenue, Saint John, New Brunswick E2K 1E5 Canada; email: donald.mcalpine@ nbm-mnb.ca

McAlpine, D.F. 2019. Occurrence of the rare marine littoral millipede, Thalassisobates littoralis (Diplopoda: Nematosomatidae), in Canada. Canadian Field-Naturalist 133(2): 136-138. https://doi.org/10.22621/cfn.v133i2.2215.

\begin{abstract}
The first Canadian occurrence of the rare, marine littoral millipede, Thalassisobates littoralis, is reported from Campobello Island in the outer Bay of Fundy, New Brunswick. One of only a few North American occurrences, this is the most northerly to date from the continent.
\end{abstract}

Key words: New Brunswick; marine habitat; marine millipede; dispersal; anthropochorus species; Thalassisobates littoralis

World-wide, Thalassisobates littoralis (Silvestri, 1903) (no common name) is one of the few marine littoral millipedes and is considered rare (Blower 1985; Barber 2009). The species occurs under stones and seaweed, in rock crevices or shingle in or above the tidal zone, and sometimes in coastal caves (Enghoff 1987; Cawley 1997). Thalassisobates littoralis has a wide but scattered distribution, with reports (often single) from the coasts of Europe, the Balearic Islands, Algeria, and the eastern United States (Enghoff 2013). The centre of its distribution appears to be the western Mediterranean basin (Kime 1999), with Kime (1999) suggesting that $T$. littoralis may have been introduced to northwestern Europe. Reporting the first North American occurrences, Enghoff (1987) speculated that the species was of European origin, but was uncertain whether its amphi-Atlantic distribution was natural or the result of human introduction. He noted that all amphi-Atlantic millipedes previously reported from North America, with one possible exception, can be regarded as introductions to the continent and that the direction of the Gulf Stream is not conducive to the natural dispersal of $T$. littoralis from Europe to North America. Thus, not unreasonably, T. littoralis has been considered of anthropochorus origin in North America (Kime 1999; Golovatch and Kime 2009).

Previously, T. littoralis has been recorded in North America only from the southwest shore of Chincoteague Island, Virginia, in 1964, from an un- known locale in Massachusetts (date unknown; Enghoff 1987), and, more recently (2005-2009), from six of the 34 islands that make up the Boston Harbor Recreation Area (Boston Harbor Islands 2014). Here, I document the first occurrence of T. littoralis from Canada and the most northerly to date on the North American continent.

On 24 September 2017, I found T. littoralis to be present, but patchily distributed, along a cobble shoreline at Herring Cove, in Herring Cove Provincial Park, Campobello Island, New Brunswick $\left(44.85956^{\circ} \mathrm{N}, 66.93188^{\circ} \mathrm{W}\right)$, along the western shore of the Bay of Fundy. Millipedes were present under patches of decomposing Bladderwrack (Fuscus vesiculosus) above and below the high-water mark (Figure 1a). Where present, millipedes were abundant (Figure 1b). In a sample of 104 specimens, 55 females and 49 males were present, close to a 1:1 sex ratio. The whole body of a single male (Figure 1c) and a series of views of the male peltogonopods, diagnostic for T. littoralis, are shown in Figure 1d-f. Voucher specimens have been deposited in the New Brunswick Museum (NBM 10776).

After the discovery of $T$. littoralis on Campobello Island, two other cobble beach sites in New Brunswick were searched along the western coast of the Bay of Fundy (Alma, $45.596739^{\circ} \mathrm{N}, 64.948728^{\circ} \mathrm{W}$, and Browns Beach, West Quaco, $45.319236^{\circ} \mathrm{N}$, $\left.65.551114^{\circ} \mathrm{W}\right)$, for T. littoralis without success. Further field investigations will be required to determine 


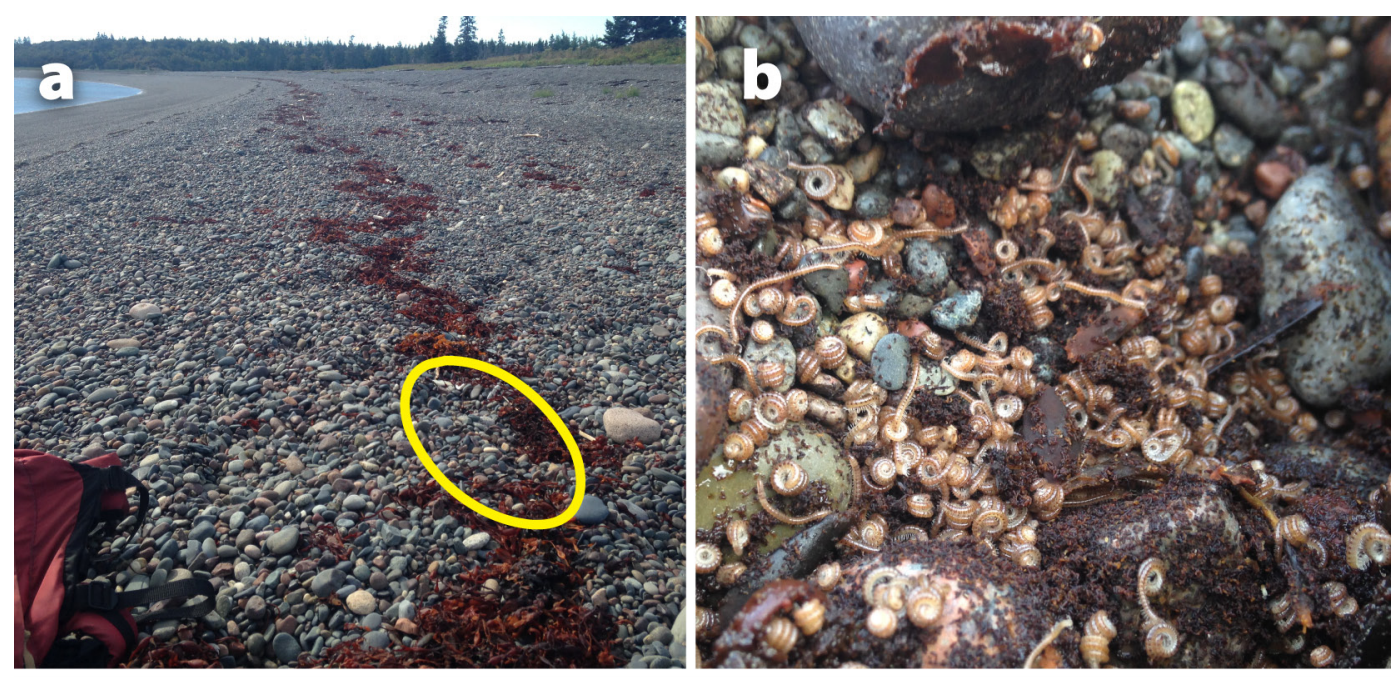

\section{C}

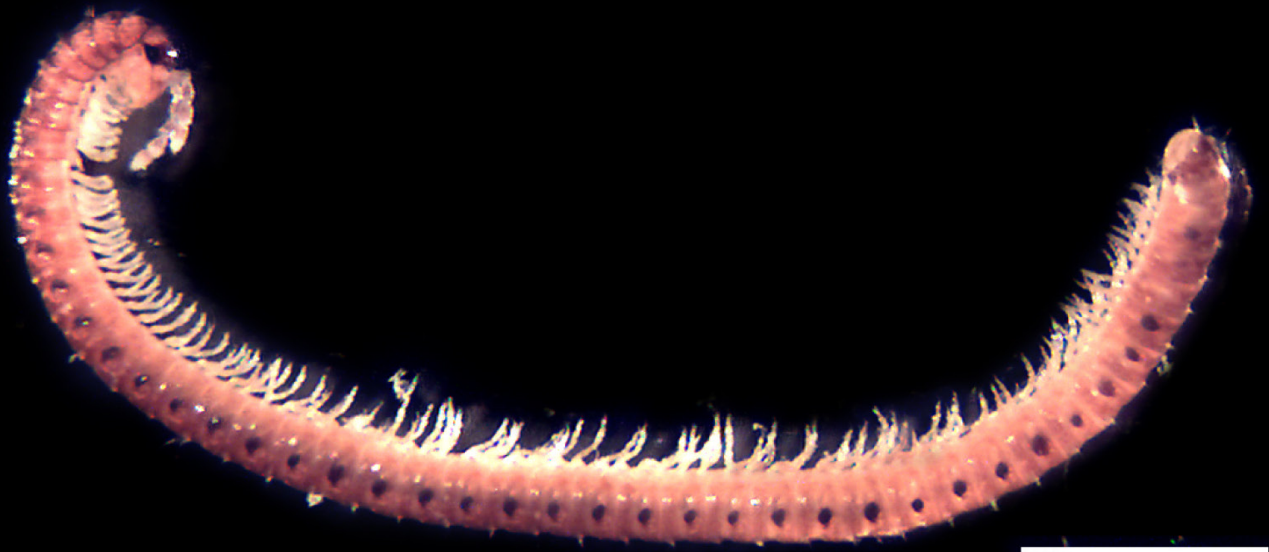

$2 \mathrm{~mm}$
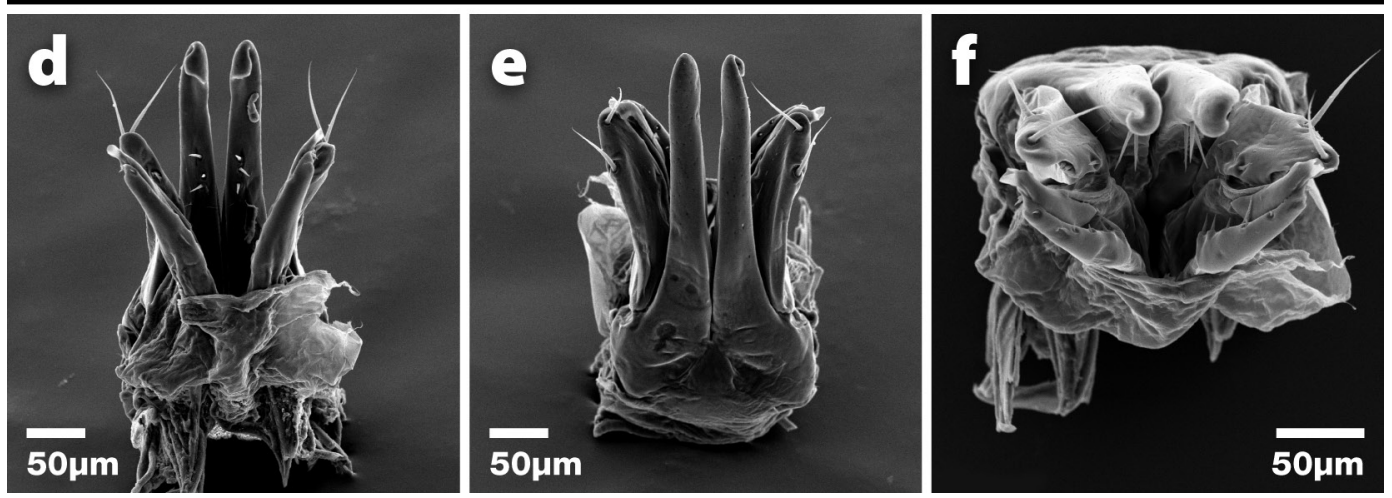

Figure 1. a. Shoreline at Herring Cove Provincial Park, New Brunswick, showing habitat for Thalassisobates littoralis. b. Concentration of millipedes under Bladderwrack (Fuscus vesiculosus). c. Habitus of male T. littoralis; scanning electron microscope images show d. superior, e. inferior, and f. distal views of the diagnostic peltogonopods. Photos: a-b. D.F. McAlpine. Photos: c-f. Nhu Trieu. 
the full distribution and true abundance of T. littoralis in Atlantic Canada.

\section{Acknowledgements}

I thank Amber McAlpine-Mills for help in the field, investigating sites at Alma and West Quaco, New Brunswick. I also thank Nhu Trieu, of the University of New Brunswick Microscopy and Microanalysis Facility, for providing Figure 1c-f.

\section{Literature Cited}

Barber, A.D. 2009. Littoral myriapods: a review. Soil Organisms 81: 735-760.

Blower, J.G. 1985. Millipedes. E.J. Brill, London, United Kingdom.

Boston Harbor Islands. 2014. All taxa biodiversity inventory: list of specimens: Thalassisobates littoralis. President and Fellows of Harvard College, Boston, Massachusetts, USA. Accessed 14 October 2019. http://140. 247.96.247/boston_islands/mantisweb/specimen_list_ bhi.php?id=59261.
Cawley, M. 1997. Distribution records for uncommon millipedes (Diplopoda) including Thalassisobates littoralis (Silvestri) new to Ireland. Irish Naturalist Journal 25: 380-382.

Enghoff, H. 1987. Thalassisobates littoralis (Silvestrian amphiatlantic millipede (Diplopoda, Julida, Nematosomatidae). Entomologist's Monthly Magazine 123: 205-206.

Enghoff, H. 2013. New montane, subterranean congeners of a littoral millipede, genus Thalassisobates (Diplopoda: Julida: Nemasomatidae). Journal of Natural History 47: 1613-1625. https://doi.org/10.1080/00222933. 2012.759289

Golovatch, S.I., and R.D. Kime. 2009. Millipede (Diplopoda) distributions: a review. Soil Organisms 81: 565597.

Kime, R.D. 1999. The continental distribution of British and Irish millipedes. Bulletin of the British Myriapod Group 15: 33-76.

Received 15 January 2019

Accepted 31 July 2019 